\title{
Prevalence of Thrombophilic Mutations in Ischemic Stroke Patients in Isparta, Turkey
}

\author{
Türkiye'nin Isparta İlinde Yaşayan İskemik İnme Geçirmiş Hastalar Arasında \\ Trombofilik Mutasyonların Görülme Sıklı̆̆ı
}

\author{
Nilgün Erten ${ }^{1}$, Serpil Demirci², Recep Sütçü3 \\ 1 Giresun University Faculty of Medicine, Department of Neurology, Giresun, Turkey \\ 2Süleyman Demirel University Faculty of Medicine, Department of Neurology, Isparta, Turkey \\ ${ }^{3}$ Katip Çelebi University Faculty of Medicine, Department of Biochemistry, İzmir, Turkey
}

\section{Summary}

Objective: The present study aimed to investigate whether the frequency of factor V, methylenetetrahydrofolate reductase (MTHFR), prothrombin, $\beta$-fibrinogen gene mutations, and human platelet alloantigens (HPA), plasminogen activator inhibitor 1 (PAI1), apolipoprotein E (APOE), and angiotensin converting enzyme (ACE) gene polymorphisms in stroke patients is higher than that in normal individuals.

Materials and Methods: Two hundred twelve patients with cerebral infarction and 238 individuals of similar age and gender with no history of stroke were included. Demographics and risk factors for cerebrovascular disease of all individuals were determined. Biochemical parameters were analyzed in serum, and electrocardiography was performed. Factor V, MTHFR, prothrombin, $\beta$-fibrinogen mutations and HPA, PAI, APOE, and ACE polymorphisms were investigated. Data were analyzed with SPSS 15.0 software using descriptive statistics, chi-square, independent two-group t-test, and logistic regression tests. Statistically significant differences in independent variables were further analyzed by logistic regression.

Results: HPA, PAI, APO, and ACE polymorphism frequency was not significantly different between the stroke and control groups. Factor V H1299R, factor V Leiden, and $\beta$ fibrinogen -455GA mutation frequencies were significantly higher in the stroke than the control group in the chi-square test, but not in logistic regression analysis.

Conclusion: Stroke etiopathogenesis is multifactorial, and prothrombin gene mutations increase the impact of existing risk factors when other risk factors are considered. (Turkish Journal of Neurology 2015; 21:42-8)

Key Words: Stroke, prothrombine gene mutations, risk factors

\section{Özet}

Amaç: Dünyanın farklı bölgelerinde kalıtsal trombofilik risk faktörlerinin görülme sıklı̆̆ı değişiklik göstermektedir. Bu çalışma ile bölgemizde iskemik inme geçirmiş hastalarda faktör V, metilentetrahidrofolat redüktaz (MTHFR), protrombin, $\beta$-Fibrinojen gen mutasyonları ve human platelet alloantigens (HPA), plazminojen aktivatör inhibitör 1 (PAİ), Apolipoprotein E (APO-E), Anjiyotensin dönüştürücü enzim (ADE) gen polimorfizmlerinin görülme sıklıklarının kontrol grubuna göre anlamlı olup olmadı̆̆ının araştırılması amaçlanmıştır.

Gereç ve Yöntem: Çalışmamıza kliniğimizde takip edilen serebral enfarkt geçirmiş 212 hasta ve inme geçirmemiş yaş ve cinsiyet özellikleri hasta grubuna benzer 238 birey alındı. Tüm katılımcıların demografik verileri ve beyin damar hastalıkları için risk faktörleri sorgulandı. Serumlarında bazı biyokimyasal parametrelere bakıldı ve elektrokardiyografileri çektirildi. Faktör V, MTHFR, protrombin, $\beta$-Fibrinojen gen mutasyonları ve HPA, PAİ, APO-E, ADE gen polimorfizmlerine bakıldı. İnme ve kontrol grubunda karşılaştırılan bağımsız değişkenlerden istatistiksel olarak anlamlı bulunanlar lojistik regresyon analizine alınd.

Address for Correspondence/Yazışma Adresi: Nilgün Erten MD, Giresun University Faculty of Medicine, Department of Neurology, Giresun, Turkey Phone: +904543101000 E-mail: nderten@hotmail.com

Received/Geliş Tarihi: 01.09.2014 Accepted/Kabul Tarihi: 11.03 .2015 
Bulgular: Çalışmamızın sonucunda inme ve kontrol grupları arasında HPA, PAİ, APO, ADE gen polimorfizmlerinin görülme sıklıkları arasında anlamlı bir fark görülmezken sadece faktör V H1299R, F V Leiden ve $\beta$ Fibrinojen -455GA mutasyonlarının görülme oranları inme geçirmiş hasta grubunda Ki-kare testine göre anlamlı yükseklikte bulundu. Ancak lojistik regresyon analizine göre ise bu mutasyonların istatistiksel olarak anlamlılıkları kayboldu.

Sonuç: Çalışmamızdan elde edilen bulgular ışı̆̆ında inme etiyopatogenezinin multifaktöriyel olduğunu ve protrombin gen mutasyonlarının ancak diğer risk faktörleri ile birlikte olduklarında bu faktörlerin neden olabilecekleri riski arttırabilecekleri düşünülmektedir. (Türk Nöroloji Dergisi 2015; 21:42-8)

Anahtar Kelimeler: İnme, protrombin gen mutasyonları, risk faktörleri

\section{Introduction}

Stroke, the third most common cause of death worldwide, is a multifactorial disease, and its incidence increases with age (1). Most cryptogenic strokes are due to hypercoagulability, responsible for $1 \%$ and $2-7 \%$ of all strokes in adults and young individuals, respectively (2). Factor V, prothrombin G20210A, methylenetetrahydrofolate reductase (MTHFR), and fibrinogen mutation, and plasminogen activator inhibitor 1 (PAI1), human platelet alloantigens (HPA), and angiotensin converting enzyme (ACE) polymorphisms cause primary hypercoagulability.

Active factor $\mathrm{V}(\mathrm{FVa})$ is the component of the prothrombinase complex that synthesizes thrombin. Active protein $\mathrm{C}$ degrades factor Va and thereby exhibits anticoagulant effects (3). The factor $\mathrm{V}$ Leiden (FVL) mutation prevents inactivation of factor Va by active protein $\mathrm{C}$ and increases predisposition to thrombosis $(4,5)$. The factor V R2 variant is expressed at lower levels than normal factor $\mathrm{V}$ and causes resistance to active protein $\mathrm{C}$ (6). MTHFR enzyme deficiency due functional polymorphisms contributes to hyperhomocysteinemia, a prominent risk factor for stroke (7-11). The prothrombin G20210A mutation leads to a 30\% increase in serum prothrombin levels compared to those in normal controls (12-14). The $\beta$-fibrinogen $-455 \mathrm{GA}$ mutation is associated with high plasma fibrinogen levels, and individuals carrying this mutation have higher fibrinogen levels than individuals carrying the $\beta$-fibrinogen - $455 \mathrm{GG}$ and $\beta$-fibrinogen - $455 \mathrm{GA}$ mutations (15).

PAI-1 inactivates plasminogen, and defects in PAI-1 lead to severe bleeding after surgery and trauma, whereas high PAI-1 levels preclude plasminogen activation and lead to a tendency for thrombosis (16). The most frequent PAI1 polymorphisms are a guanine insertion $(5 \mathrm{G})$ and deletion $(4 \mathrm{G})$ at position 675 of the PAI1 promoter. The PAI1 4G/4G genotype leads to $25 \%$ higher PAI-1 levels than the PAI1 5G/5G genotype (17). Activated thrombocytes aggregate via glycoprotein (GP) 2b/3a receptors and fibrinogen to form the primary hemostatic plug (18). GP $3 a$, $1 \mathrm{~b}, 2 \mathrm{~b}$ and $1 \mathrm{a}$, also named human platelet alloantigens (HPA)-1, $-2,-3$, and -5 , respectively, are the major GPs in adhesion and aggregation $(19,20)$. ACE converts angiotensin 1 to 2, leading to vascular hypertrophy and vasoconstriction, and reduces bradykinin, which exhibits vasodilator functions (21). ACE polymorphisms are defined by the presence (I allele) or absence ( $D$ allele) of a repetitive sequence in intron $16(22,23)$. Homozygosity for the D allele causes $56 \%$ higher ACE activity than homozygosity for the I allele (24). A moderate increase in ACE activity is observed in the ACE I/D genotype (25). Genetic factors determine atherosclerosis development by regulating lipoprotein levels via apolipoproteins, such as apolipoprotein E (APOE), a ligand for low-density lipoprotein (LDL) receptors (26-28). The APOE allelic variants are $\varepsilon 2, \varepsilon 3, \varepsilon 4$, and combinations of these alleles lead to the production of the isomorphic proteins E2, E3, and E4 (29). The presence of APOE4 leads to higher plasma LDL concentrations than the presence of APOE2, whereas the presence of both APOE2 and APOE4 leads to higher triglyceride concentrations than the presence of APOE3 $(30,31)$.

The effect of prothrombin gene mutations in the etiopathogenesis of cerebrovascular events is not clear. This study aimed to compare the frequency of prothrombin gene mutations in ischemic stroke patients and controls.

\section{Materials and Methods}

This study included 212 ischemic stroke patients followed up at Research and Training Hospital Neurology Clinic, Süleyman Demirel University, between 2007 and 2009, and 238 individuals of similar age and same gender, but without a history of stroke. Ethical approval was obtained from the Institutional Ethics Committee of Süleyman Demirel University (14.01.2009, \#7). All participants were asked to fill out a volunteer consent form.

The age, smoking habits, alcohol consumption, and diet of all participants were recorded. Dietary habits were defined as (a) primarily red meat consumption or (b) a Mediterranean diet (fruit, vegetable, and white meat consumption). Participants were questioned for a history of hypertension, diabetes, cardiac valve disease, and arrhythmia. Biochemical profiles of all patients were recorded. The distribution of ischemic stroke patients according to the "Trial of Org 10172 in Acute Stroke Treatment" (TOAST) was determined (Table 1).

Three milliliters of venous blood was collected in EDTAcontaining tubes to analyze factor V, MTHFR, prothrombin, and beta-fibrinogen mutations and HPA, PAI1, APOE, and ACE polymorphisms. Genomic DNA sequences were amplified by multiplex polymerase chain reaction, and mutations were analyzed by reverse in situ hybridization with "Cardiovascular Disease Strip Assay" (Vienna Lab, Austria).

Table 1. Distribution of patients with ischemic stroke according to "Trial of Org 10172 in Acute Stroke Treatment" criteria

\begin{tabular}{ll}
\hline Type of stroke & $\mathbf{n}(\%)$ \\
\hline Cause undetermined & $108(50.9)$ \\
Lacunar infarction & $59(27.8)$ \\
Cardioembolism & $26(12.3)$ \\
Large artery atherosclerosis & $19(9.0)$ \\
Due to other causes & - \\
Total & $212(100.0)$
\end{tabular}


Data have been presented as counts, percentages, mean, standard deviation, and minimum and maximum values. Data were analyzed with SPSS 15.0 software by using descriptive statistics, chi-square, independent samples t-test, and logistic regression test. Statistically significant differences were further analyzed by a logistic regression test. $\mathrm{P}<0.05$ was considered statistically significant.

\section{Results}

The age of the stroke patients ranged between 17 and 96 years 102 patients were female and 110 male. The age of the controls ranged between 28 and 90 years; 130 patients were female and 108 male. Gender distribution did not significantly differ between the stroke and the control groups $(\mathrm{p}=0.142)$. The mean age was higher in the stroke than the control group $(\mathrm{p}=0.002)$. Mean systolic and diastolic blood pressures were higher in stroke patients than in controls $(\mathrm{p}=0.041$ and $\mathrm{p}=0.501$, respectively). The incidence of individuals adhering to a Mediterranean diet was lower in the stroke than in the control group $(\mathrm{p}=0.016)$. The incidence of arrhythmia, cardiac failure, and atrial fibrillation and of other diseases such as cardiac valve and coronary artery disease in stroke patients was higher than in controls $(\mathrm{p}<0.001$ and $\mathrm{p}<0.001$, respectively). There were more male individuals and the incidence of smoking, low alcohol consumption, and diabetes, and lipid levels were higher in the stroke than in the control group $(\mathrm{p}>0.05)$. The mean glucose, blood urea nitrogen (BUN), homocysteine, and free $\mathrm{T} 4$ levels in stroke patients were higher than those in the control group $(\mathrm{p}<0.05)$, whereas the mean total and high density lipoprotein (HDL) cholesterol, free T3, and thyroid stimulating hormone (TSH) levels in stroke patients were lower than those in controls $(\mathrm{p}<0.05$, Table 2$)$.

Among the independent variables tested in the established model, the effects of HDL cholesterol, T3 and T4 thyroid hormones, and arrhythmia were statistically significant $(\mathrm{p}<0.05)$. According to the odds ratio, one unit decrease in HDL cholesterol level increased stroke risk by 0.9-fold. One unit decrease in T3 and $\mathrm{T} 4$ caused a 0.5 - and 6.4-fold increase in stroke risk, respectively. The stroke risk for patients exhibiting arrhythmia was 5.9-fold higher than that for patients who did not have arrhythmia. Conversely, the effects of other independent variables on the model were not significant (Table 3, 4, and 5).

\section{Discussion}

The impact of prothrombin mutations in venous thromboembolisms is clear, and current research focuses on their potential role in arterial stroke. However, epidemiological studies investigating the correlation of prothrombin mutations and ischemic stroke are controversial.

Several studies have reported that FVL mutation is not an important risk factor for ischemic stroke (32-36). In contrast, the present study demonstrated a higher frequency of homozygous and heterozygous FVL mutations in stroke patients than in controls. The frequency of this mutation in stroke patients was higher than that reported in previous studies (33-39). Notably, the frequency of the FVL mutation in healthy individuals was similar to that of the general society. Furthermore, factor V mutations might increase stroke risk in young patients presenting with stroke originating from a cardiac embolism (40). The FVL mutation might slightly increase the risk of arterial thrombotic events compared to that of venous thromboembolism, and the effect is more pronounced in people younger than 55 and in women (41). The reported higher FVL mutation frequency in ischemic stroke patients suggested its relevance in ischemic stroke development, although it did not increase risk in the presence of other risk factors.

Previous research indicates that factor V R2 mutation increases thrombosis risk although it is not a risk factor for cerebrovascular diseases $(42,43)$. However, the number of studies was limited. In the present study, the frequency of factor V R2 mutation was significantly higher in ischemic stroke patients than in controls, suggesting an important role for this mutation in ischemic stroke development. However, in the presence of other risk factors, the factor V R2 mutation does not pose a significant risk.

The relationship between the MTHFR C677T mutation and ischemic stroke remains unclear (44). MTHFR mutations cause a slightly higher risk of arterial thrombotic events than of venous thromboembolism $(41,45)$. In accordance with previous findings, our study indicates that the MTHFR C677T mutation is frequent in healthy individuals and that there is no association between this mutation and stroke $(46,47)$. Several studies reported that the MTHFR C677T mutation is not a risk factor for ischemic stroke $(44,46,48)$. Conversely, this mutation is associated with stroke in Asian populations $(45,49)$. Similarly, a report on young patients who experienced a stroke originating from a cardiac embolism indicated that the MTHFR gene mutation increases stroke risk (40). We did not observe an association of the MTHFR A1298C and $\mathrm{C} 677 \mathrm{~T}$ mutations with stroke, confirming a study addressing prevalence of the A1298C mutation in a healthy population in Turkey, and suggesting that MTHFR mutations are not a risk for ischemic stroke (47).

The role of the prothrombin G20210A mutation in ischemic stroke is controversial $(34,40,41,48,50-53)$. The present study shows that the prothrombin G20210A mutation is not associated with stroke and is not important in the case of ischemic stroke.

Although previous studies demonstrated that the $\beta$-fibrinogen-455 GA mutation increases ischemic stroke risk, the findings are controversial (54-57). Although our results indicate that the $\beta$-fibrinogen $-455 \mathrm{GA}$ mutation is associated with ischemic stroke, this mutation did not pose significant risk in the presence of other risk factors.

PAI1 polymorphisms are a risk factor for ischemic stroke, whereas the PAI1 $4 \mathrm{G} / 4 \mathrm{G}$ polymorphism might protect from ischemic stroke (58-63). Venous thromboembolism is more frequent than ischemic stroke in young individuals, and reduced fibrinolytic capacity due to elevated PAI-1 levels predisposes to venous thromboembolism but not to ischemic stroke (64).

The significance of HPA polymorphisms in stroke development is controversial. HPA polymorphisms are associated with stroke; heterozygosity for the GP 3 a A2 allele is a risk factor for atherosclerotic stroke in young individuals, and the HPA3 b/b polymorphism and homozygosity for the HPA1b polymorphism are associated with ischemic stroke (65-67). However, HPA polymorphisms are not associated with hemorrhagic stroke, and the GP 3 a A2 allele is not a risk for myocardial infarction, stroke, or venous thrombosis $(67,68)$. Previous work indicated that the 
GP 3a polymorphism is a moderate risk factor for large vein atherosclerosis-induced stroke and revealed that heterozygosity for the GP 3 a A2 allele is an independent risk factor (69). Furthermore, GP 1a (HPA5) is correlated weakly with ischemic stroke (70). In the present study, the frequency of the GP 3 a A2 polymorphism did not differ between stroke patients and controls, indicating that the GP $3 \mathrm{a} A 2$ polymorphism is not a risk factor for ischemic stroke.

Multiple studies have suggested that the ACE I/D polymorphism is not a risk factor for ischemic stroke, although the frequency of I/I and D/D polymorphisms differs between stroke patients according to sex $(22,71,72)$. In agreement with these findings, we did not observe a difference in the frequency of the ACE I/I, I/D, and D/D polymorphisms between stroke patients and controls, confirming that this polymorphism is not a risk factor for ischemic stroke. However, homozygosity for the ACE $\mathrm{D} / \mathrm{D}$ polymorphism confers a higher risk for stroke than the I/D and I/I genotypes $(73,74)$.

The frequency of the APOE $\varepsilon 4$ allele is higher in stroke patients than in controls (75-77). Conversely, other studies reported that the APOE $\varepsilon 4$ allele does not increase ischemic stroke risk $(78,79)$. No significant difference has been reported between hemorrhagic and ischemic stroke patients and controls for the frequency of the APOE, $\varepsilon 2 / \varepsilon 2, \varepsilon 2 / \varepsilon 3, \varepsilon 3 / \varepsilon 3$, and $\varepsilon 3 / \varepsilon 4$ polymorphisms (71). Data from the present study support the notion that APOE gene polymorphisms are not associated with stroke.

In conclusion, the results indicated that only factor V H1299R, FVL, and $\beta$-fibrinogen $-455 \mathrm{GA}$ mutations are associated with

Table 2. Comparison of the data for the variables for stroke patients and controls

\begin{tabular}{|c|c|c|c|}
\hline Variables & Ischemic stroke & Control & $\mathrm{p}$ \\
\hline Age & $65.80 \pm 14.41$ & $61.82 \pm 13.22$ & 0.002 \\
\hline Sex, female (\%) & 47.9 & 54.6 & 0.142 \\
\hline Smoking (\%) & 38.2 & 37.0 & 0.777 \\
\hline Alcohol (\%) & 13.9 & 17.2 & 0.312 \\
\hline Diabetes (\%) & 29.8 & 23.5 & 0.120 \\
\hline Cardiac issues (\%) & 39.5 & 18.5 & 0.000 \\
\hline Systolic blood pressure, $\mathrm{mmHg}$ & $141.03 \pm 26.05$ & $136.30 \pm 24.24$ & 0.041 \\
\hline Diastolic blood pressure, $\mathrm{mmHg}$ & $83.7 \pm 11.23$ & $83.15 \pm 9.66$ & 0.501 \\
\hline Cardiac Arrhythmia (\%) & 26.1 & 3.8 & 0.000 \\
\hline Glucose (mg/dl) & $121.30 \pm 44.67$ & $106.10 \pm 42.52$ & 0.000 \\
\hline LDL cholesterol (mg/dl) & $113.72 \pm 37.21$ & $115.92 \pm 41.73$ & 0.544 \\
\hline VLDL cholesterol (mg/dl) & $28.07 \pm 17.15$ & $29.96 \pm 18.86$ & 0.253 \\
\hline Triglyceride (mg/dl) & $140.50 \pm 85.68$ & $149.85 \pm 94.34$ & 0.258 \\
\hline Vitamin B12 (pg/ml) & $473.81 \pm 363.70$ & $478.89 \pm 388.57$ & 0.883 \\
\hline Homocysteine $(\mu \mathrm{mol} / \mathrm{l})$ & $14.23 \pm 7.39$ & $12.87 \pm 6.78$ & 0.039 \\
\hline $\mathrm{fT} 3(\mathrm{pg} / \mathrm{ml})(1.71-3.71)$ & $2.48 \pm 1.01$ & $2.78 \pm 0.60$ & 0.000 \\
\hline fT4 (ng/dl) (0.71-1.47) & $1.19 \pm 0.84$ & $0.91 \pm 0.25$ & 0.000 \\
\hline TSH $(\mathrm{pg} / \mathrm{ml})(0.35-4.94)$ & $1.16 \pm 1.70$ & $1.56 \pm 2.29$ & 0.032 \\
\hline
\end{tabular}

LDL: Low-density lipoprotein, HDL: High density lipoprotein, TSH: Thyroid stimulating hormone, BUN: Blood urea nitrogen

Table 3. Frequency of prothrombin mutations in stroke patients and controls

\begin{tabular}{lllll}
\hline \multirow{2}{*}{ Mutation Type } & \multicolumn{2}{c}{ Ischemic Stroke } & \multicolumn{2}{c}{ Control } \\
& Heterozygous (\%) & Homozygous (\%) & Heterozygous (\%) & Homozygous (\%) \\
\hline Factor -V (H1299R)** & 43.7 & - & 20.6 & 0.4 \\
B- Fibrinogen (-455G>A)** & 39.9 & 5.9 & 43.7 & 1.3 \\
MTHFR (A1298C) & 26.5 & 10.9 & 41.2 & 16.4 \\
Factor -XIII (V34L) & 41.2 & 1.7 & 25.6 & 3.4 \\
Factor -V Leiden (G1691A)** & 13.9 & 1.3 & 8.8 & - \\
MTHFR (C677T) & 32.8 & 22.7 & 23.5 & 28.2 \\
Prothrombin (G20210A) & 6.3 & - & 4.2 & - \\
\hline
\end{tabular}

${ }^{* *}$ Chi-square test, $\mathrm{p}<0.05$. MTHFR: Methylenetetrahydrofolate reductase 
stroke, and prothrombin gene mutations are stroke risk factors only when they occur in association with other factors.

Ethics Committee Approval: The study were approved by the Süleyman Demirel University of Local Ethics Committee (Ethics Board Decision; dated 14.01.2009 No. 7).

Informed Consent: Consent form was filled out by all participants.
Concept: Nilgün Erten, Serpil Demirci

Design: Nilgün Erten, Serpil Demirci

Data Collection or Processing: Nilgün Erten

Analysis or Interpretation: Nilgün Erten, Recep Sütçü

Literature Search: Nilgün Erten

Writing: Nilgün Erten

Peer-review: Externally peer-reviewed.

Table 4. Frequency of prothrombotic gene polymorphisms in stroke patients and controls

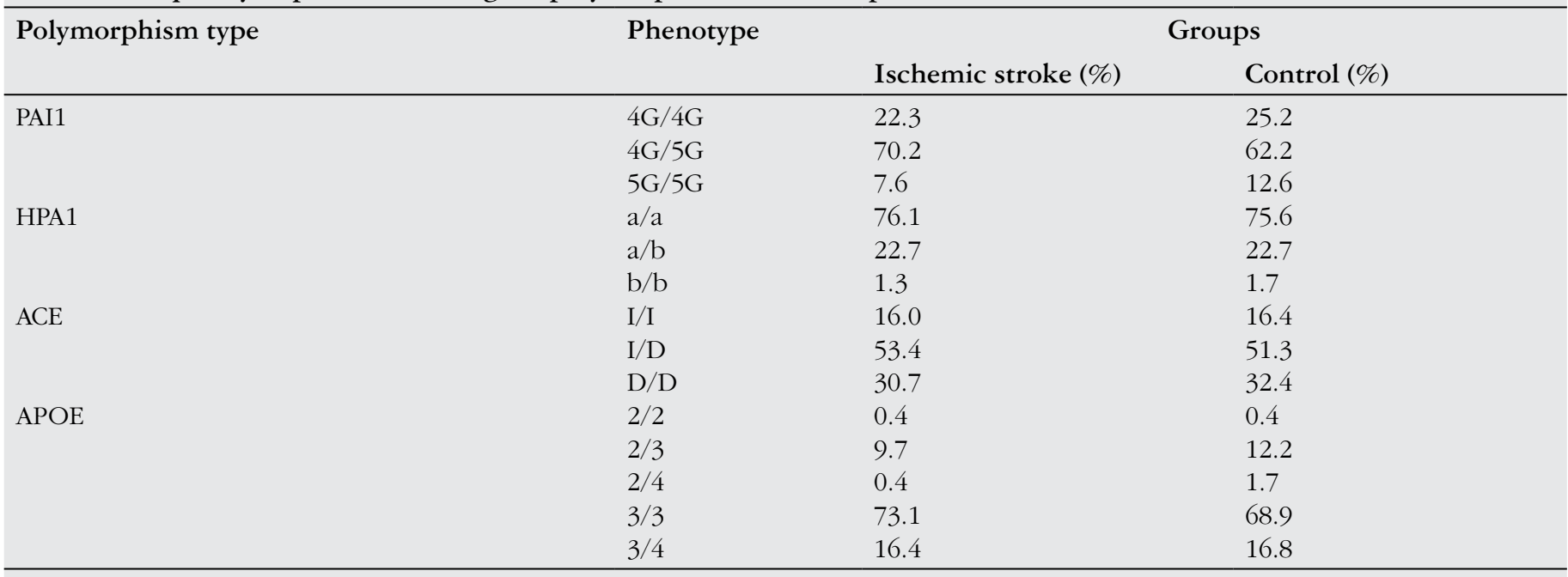

ACE: Angiotensin converting enzyme, APOE: Apolipoprotein E, PAI1: Plasminogen activator inhibitor 1, HPA: Human platelet alloantigens

Table 5. Results of logistic regression analysis for the patients

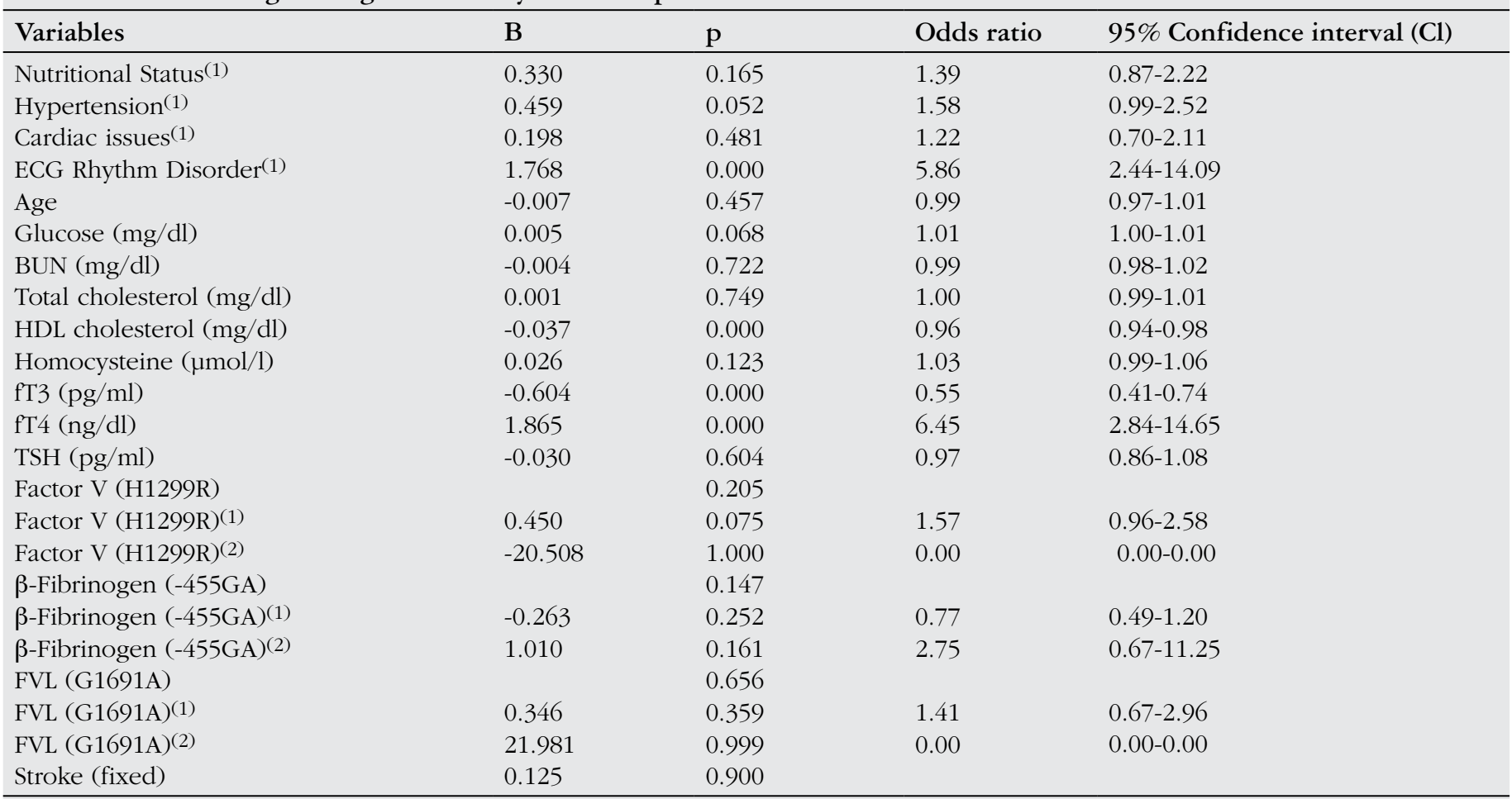

FVL: Factor V Leiden, HDL: High density lipoprotein, TSH: Thyroid stimulating hormone, BUN: Blood urea nitrogen

${ }^{(1)}$ Each unit represents an increase or heterozygous mutations. ${ }^{(2)}$ Represents a homozygous mutation. Coefficients (B), significance levels, odds ratio, and $95 \%$ confidence interval in logistic regression analysis. 
Conflict of Interest: No conflict of interest was declared by the authors.

Financial Disclosure: This project supported by Süleyman Demirel University research project management unit by number 1783-TU-09 project.

\section{References}

1. Dickerson LM, Carek PJ, Quattlebaum RG. Prevention of recurrent ischemic stroke. Am Fam Physician 2007;76:382-388.

2. Biler J, Love BB. Ischemic cerebrovascular disease. In: Bradley WG (eds). Neurology in Clinical Practice. 14th ed. Philadelphia: Butterworth Heinemann 2004:1197-1251.

3. Dahlback B. Inherited thrombophilia: resistance to activated protein $\mathrm{C}$ as a pathogenetic factor of venous thromboembolism. Blood 1995;85:607-614.

4. Bertina RM, Koeleman BP, Koster T, Rosendaal FR, Dirven RJ, de Ronde $\mathrm{H}$, van der Velden PA, Reitsma PH. Mutation in blood coagulation factor V associated with resistance to activated protein C. Nature 1994;369:64-67.

5. Sun X, Evatt B, Griffin JH. Blood coagulation abnormality associated with resistance to activated protein $\mathrm{C}$ in venous thrombophylia. Blood 1994;83:31203125.

6. Zaatari GS, Otrock ZK, Sabbagh AS, Mahfouz RA. Prevalence of factor V R2 (H1299R) polymorphism in the Lebanese population. Pathology 2006;38:442444

7. Hademenos GJ, Alberts MJ, Awad I, Mayberg M, Shepard T, Jagoda A, Latchaw RE, Todd HW, Viste K, Starke R, Girgus MS,Marler J, Emr M, Hart $\mathrm{N}$. Advances in the genetics of cerebrovascular diseases and stroke. Neurology 2001;56:997-1008.

8. Ho GY, Eikelboom JW, Hankey GJ, Wong CR, Tan SL, Chan JB, Chen CP. Methylenetetrahydrofolate reductase polymorphisms and homocysteinelowering effect of vitamin therapy in Singaporean stroke patients. Stroke 2006;37:456-460

9. Wu Y, Tomon M, Sumino K. Methylenetetrahydrofolate reductase gene polymorphism and ischemic stroke: sex difference in Japanese. Kobe J Med Sci 2001;47:255-262.

10. Emiroğulları EF, Saatçi Ç, Ünal A, Özkul Y. Arteriyo-venöz fistül trombozu gelişen ve gelişmeyen kronik böbrek yetersizliği olan hastalarda metilentetrahidrofolate redüktaz polimorfizmlerinin araştırılması. Sağlık Bilimleri Dergisi 2007;16:121-128.

11. Tepeli E, Müslümanoğlu MH, Uludağ A, Atlı E, Uzun D, Artan S. Eskişehir ilinde idiyopatik tekrarlayan gebelik kayıpları ile MTHFR C677T ve A1298C polimorfizmleri arasındaki ilişki. Osmangazi Tıp Dergisi 2007;29:1-11.

12. Akbaş F, Oral E. Kalıtsal trombofili ve gebelik. Perinatoloji Dergisi 2002;10:17.

13. Sucak G, Haznedar R. Trombofili. Türkiye Klinikleri Cerrahi Dergisi 2000;5: 59-64.

14. Pratt RW, Adams D, Balmaceda C. Hematologic and related diseases. In: Rowland LP (ed). Merritt's Neurology. 11th ed. Philadelphia: Lippincott Williams \& Wilkins; 2005:1050-1064.

15. Behague I, Poirier O, Nicaud V, Evans A, Arveiler D, Luc G, Cambou JP, Scarabin PY, Bara L, Green F, Cambien F. Beta fibrinogen gene polymorphisms are associated with plasma fibrinogen and coronary artery disease in patient with myocardial infarction. The ECTIM Study. Etude Cas-Temoins sur l'Infarctus du Myocarde. Circulation 1996;93:440-449.

16. Schleef RR, Higgins DL, Pillemer E, Levitt LJ. Bleeding diathesis due to decreased functional activity of type 1 plasminogen activator inhibitor. J Clin Invest 1989;83:1747-1752.

17. Nowak-Göttl U, Sträter R, Kosch A, von Eckardstein A, Schobess R, Luigs P, Nabel P, Vielhaber H, Kurnik K, Junker R. he plasminogen activator inhibitor (PAI)-1 promoter $4 \mathrm{G} / 4 \mathrm{G}$ genotype is not associated with ischemic stroke in a population of German children. Childhood Stroke Study Group. Eur J Haematol 2001;66:57-62

18. Dahlback B. Blood coagulation. Lancet 2000;355:1627-1632.

19. Sperr WR, Huber K, Roden M, Janisiw M, Lang T, Graf S, Maurer G, Mayr WR, Panzer S. Inherited platelet glycoprotein polymorphisms and a risk for coronary heart disease in young central Europeans. Thromb Res 1998;90:117123
20. Thornton MA, Poncz M, Korostishevsky M, Yakobson E, Usher S, Seligsohn U, Peretz $\mathrm{H}$. The human platelet alphallb gene is not closely linked to its integrin partner beta3. Blood 1999;94:2039-2047.

21. Casas JP, Hingorani AD, Bautista LE, Sharma P. Meta-analysis of genetic studies in ischemic stroke. Arch Neurol 2004;61:1652-1661.

22. Sipahi T, Güldiken B, Üstündağ S, Turgut N, Budak M, Cakine S, Özkan H, Şener S. The association of gene polymorphisms of the angiotensin-converting enzyme and angiotensin II receptor type 1 with ischemic stroke in Turkish subjects of Trakya region. Balkan Med J 2009;26:1-8.

23. Hubert C, Houot AM, Corvol P, Soubrier F. Structure of the angiotensin I-converting enzyme gene. Two alternate promoters correspond to evolutionary steps of a duplicated gene. J Biol Chem 1991;266:15377-15383.

24. Agerholm-Larsen B, Nordestgaard BG, Tybjaerg-Hansen A. ACE gene polymorphism in cardiovascular disease: meta-analyses of small and large studies in whites. Arterioscler Thromb Vasc Biol 2000;20: 484-492.

25. Rigat B, Hubert C, Alhenc-Gelas F, Cambien F, Corvol P, Soubrier F. An insertion/deletion polymorphism in the angiotensin I converting enzyme gene accounts for half the variance of serum enzyme levels. J Clin Invest 1990;86:1343-1346

26. Ağaçhan B, Yılmaz H, Öztürk O, Ergen HA, İsbir CS. Aterosklerozda apolipoprotein E, okside-LDL ve lipid profili ilişkisinin araştırılması. Fırat Üniversitesi Sağlık Bilimleri Dergisi 2005;19:193-197.

27. Coşkun T. Nütrisyonel genomik. Çocuk Sağlığ 1 ve Hastalıkları Dergisi 2007;50:47-66.

28. Öztürk Ş. Apolipoprotein E ve Alzheimer hastalığı. Demans Dizisi 1999;1:6267.

29. Mahley RW. Apolipoprotein E: cholesterol transport protein with expanding role in cell biology. Science 1988;240:622-630.

30. Mahley RW, Huang Y. Apolipoprotein E: from atherosclerosis to Alzheimer's disease and beyond. Curr Opin Lipidol 1999;10:207-217.

31. Hsu CC, Kao WH, Coresh J, Pankow JS, Marsh-Manzi J, Boerwinkle E, Bray MS. Apolipoprotein E and progression of chronic kidney disease. JAMA 2005;293:2892-2899.

32. Chaturvedi S, Joshi N, Dzieczkowski J. Activated protein C resistance in young African American patients with ischemic stroke. J Neurol Sci 1999;163:137139.

33. Ridker PM, Henekens CH, Lindpainter K, Stampfer MJ, Eisenberg PR, Miletich JP. Mutation in the gene coding for coagulation factor $\mathrm{V}$ and the risk of myocardial infarction, stroke, and venous thrombosis in apparently healthy men. N Engl J Med 1995;332:912-917.

34. Longstreth WT Jr, Rosendaal FR, Siscovick DS, Vos HL, Schwartz SM, Psaty BM, Raghunathan TE, Koepsell TD, Reitsma PH. Risk of stroke in young women and two prothrombotic mutation: factor $\mathrm{V}$ Leiden and prothrombin gene variant (G20210A). Stroke 1998;29:577-580.

35. Press RD, Liu XY, Beamer N, Coull BM. Ischemic stroke in the elderly: Role of common factor $\mathrm{V}$ mutation causing resistance to activated protein $\mathrm{C}$. Stroke 1996;27:44-48.

36. Hamedani AG, Cole JW, Cheng Y, Sparks MJ, O'Connell JR, Stine OC, Wozniak MA, Stern BJ, Mitchell BD, Kittner SJ. Factor V leiden and ischemic stroke risk: the Genetics of eErly Onset Stroke (GEOS) study. J Stroke Cerebrovasc Dis 2013;22:419-423.

37. Kontula K, Ylikorkala A, Miettinen H, Vuorio A, Kauppinen-Mäkelin R, Hämäläinen L, Palomäki H, Kaste M. Arg506GIn factor V mutation (factor Vleiden) in patients with ischemic cerebrovascular disease and survivors of myocardial infarction. Thromb Haemost 1995;73:558-560.

38. Albucher JF, Guiraud-Chaumeil B, Chollet F, Cadroy Y, Sie P. Freguency of resistance to activated protein $\mathrm{C}$ due to factor $\mathrm{V}$ mutation in young patients with ischemic stroke. Stroke 1996;27:766-767.

39. Gürgey A, Mesci L. The prevalence of factor V Leiden (G1691A) mutation in Turkey. Turk J Pediatr 1997;39:313-315.

40. Dobrynina LA, Kalashnikova LA, Patrusheva NL, Kovalenko TF, Patrushev LI Polymorphism of 5,10-methylenetetrahydropholate reductase, prothrombin, and coagulation factor $\mathrm{V}$ genes in young patients with ischemic stroke. Klin Med (Mosk) 2012;90:37-40.

41. Kim RJ, Becker RC. Association between factor V Leiden, prothrombin G20210A, and methylenetetrahydrofolate reductase C677T mutations and events of the arterial circulatory system: a meta-analysis of published studies. Am Heart J 2003;146:948-957. 
42. Margaglione M, Bossone A, Coalizzo D, D'Andrea G, Brancaccio V, Ciampa A, Grandone E, Di MG. FV HR2 haplotype as additional inherited risk factor for deep vein thrombosis in individuals with a high-risk profile. Thromb Haemost 2002;87:32-36.

43. Lecumberri R, Ceberio I, Montes R, Lopez ML, Alberca I, Rocha E. Evaluation of the factor V HR2 haplotype as a risk factor for ischemic cerebrovascular disease. Haematologica 2003;88:236-237.

44. Uçar F, Sönmez M, Ovali E, Ozmenoglu M, Karti SS, Yilmaz M, Pakdemir A. MTHFR C677T polymorphism and its relation to ischemic stroke in the Black Sea Turkish population. Am J Hematol 2004;76: 40-43.

45. Xin XY, Song YY, Ma JF, Fan CN, Ding JQ, Yang GY, Chen SD. Gene polymorphisms and risk of adult early onset ischemic stroke: A meta-analysis. Thromb Res 2009;124:619-624.

46. Lalouschek W, Aull S, Serles W, Schnider P, Mannhalter C, Pabinger-Fasching I, Deecke L, Zeiler K. C677T MTHFR mutation and factor V Leiden mutation in patients with TIA/minor stroke: a case-control study. Thromb Res 1999;93:6169.

47. Sazci A, Ergul E, Kaya G, Kara I. Genotype and allele frequencies of the polymorphic methylenetetrahydrofolate reductase gene in Turkey. Cell Biochem Funct 2005;23:51-54.

48. Lopaciuk S, Bykowska K, Kwiecinski H, Mickielewicz A, Czlonkowska A, Mendel T, Kuczynska-Zardzewialy A, Szelagowska D, Windyga J, Schröder W, Herrmann FH, Jedrzejowska H. Factor V Leiden, prothrombin gene G20210A variant, and methylenetetrahydrofolate reductase C677T genotype in young adults with ischemic stroke. Clin Appl Thromb Hemost 2001;7:346-350.

49. Li Z, Sun L, Zhang H, Liao Y, Wang D, Zhao B, Zhu Z, Zhao J, Ma A, Han Y, Wang Y, Shi Y, Ye J, Hui R; Multicenter Case-Control Study in China. Elevated plasma homocysteine was associated with hemorrhagic and ischemic stroke, but methylenetetrahydrofolate reductase gene $\mathrm{C} 677 \mathrm{~T}$ polymorphism was a risk factor for thrombotic stroke: a Multicenter Case-Control Study in China. Stroke 2003;34:2085-2090

50. Madonna P, de Stefano V, Coppola A, Cirillo F, Cerbone AM, Orefice G, Di Minno G. Hyperhomocysteinemia and other inherited prthrombotic conditions in young adults with a history of ischemic stroke. Stroke 2002;33:51-56.

51. Saadatnia M, Salehi M, Amini G, Seyyed Agha Miri N. The impact of prothrombin (G20210A) gene mutation on stroke in youths. ARYA Atheroscler 2012;8:9-11.

52. De Stefano V, Chiusolo P, Paciaroni K, Casorelli I, Rossi E, Molinari M, Servidei S, Tonali PA, Leone G. Prothrombin G20210A mutant genotype is a risk factor for cerebrovascular ischemic disease in young patients. Blood 1998;91:35623565.

53. Gomez E, van der Poel SC, Jansen JH, van der Reijden BA, Lowenberg B. Rapid simultaneous screening of factor V Leiden and G20210A prothrombin variant by multiplex polymerase chain reaction on whole blood. Blood 1998;91:22082209.

54. Martiskainen M, Pohjasvaara T, Mikkelsson J, Mäntylä R, Kunnas T, Laippala P, Ilveskoski E, Kaste M, Karhunen PJ,Erkinjuntti T. Fibrinogen gene promoter -455 A allele as a risk factor for lacunar stroke. Stroke 2003;34:886-891.

55. Nishiuma S, Kario K, Yakushijin K, Maeda M, Murai R, Matsuo T, Ikeda U, Shimada K, Matsuo M. Genetic variation in thepromoter region of yhe betafibrinogen gene is associated with ischemic stroke in a Japanese population. Blood Coagul Fibrinolysis 1998;9:373-379.

56. Yuan XD, Wang SJ, Xu YR, Gao J, Yang N, Li J, Li HF. Relationship between multi-locus fibrinogen polymorphisms and fibrinogen concentration, molecular reactivity and cerebral infarction. Zhonghua Xue Ye Xue Za Zhi 2009;30:582587.

57. Kessler C, Spitzer C, Stauske D, Mende S, Stadlmüller J, Walther R, Rettig $\mathrm{R}$. The apolipoprotein $\mathrm{E}$ and beta-fibrinogen G/A-455 gene polymorphisms are associated with ischemic stroke involving largevessel disease. Arterioscler Thromb Vasc Biol 1997;17:2880-2884.

58. Wiklund PG, Nilsson L, Ardnor SN, Eriksson P, Johansson L, Stegmayr B, Hamsten A, Holmberg D, Asplund K. Plasminogen activator inhibitor- 1 $4 \mathrm{G} / 5 \mathrm{G}$ polymorphism and risk of stroke:replicated findings in two nested casecontrol studies based on independent cohorts. Stroke 2005;36:1661-1665.

59. Bang CO, Park HK, Ahn MY, Shin HK, Hwang KY, Hong SY. 4G/5G polymorphism of the plasminogen activator inhibitor-1 gene and insertion/ deletion polymorphism of the tissue-type plasminogen activator gene in atherothrombotic stroke. Cerebrovasc Dis 2001;11:294-299.
60. de Paula Sabino A, Ribeiro DD, Domingueti CP, Dos Santos MS, Gadelha T, Dusse LM, das Graças Carvalho M, Fernandes AP. Plasminogen activator inhibitor-1 4G/5G promoter polymorphism and PAI-1 plasma levels in young patients with ischemic stroke. Mol Biol Rep 2011;38:5355-5360.

61. Endler G, Lalouschek W, Exner M, Mitterbauer G, Haring D, Mannhalter C. The $4 \mathrm{G} / 4 \mathrm{G}$ genotype at nucleotide position -675 in the promotor region of the plasminogen activator inhibitor 1 (PAI-1) gene is less freguent in young patientswith minor stroke than in controls. Br J Haematol 2000;110:469-471.

62. Roest M, van der Schouw YT, Banga JD, Tempelman MJ, de Groot PG, Sixma JJ, Grobbee DE. Plasminogen activator inhibitor $4 \mathrm{G}$ polymorphism is associated with decreased risk of cerebrovascular mortality in older women. Circulation 2000;101:67-70.

63. HoekstraT, Geleijnse JM, Kluft C, Giltay EJ, Kok FJ, Schouten EG. 4G/4G genotype of PAI-1 gene is associated with reduced risk of stroke in elderyl. Stroke 2003;34:2822-2828.

64. Skov J, Sidelmann JJ, Bladjerg EM, Jespersen J, Gram J. Difference in fibrinolytic capacity in young patients with venous thrombosis or ischaemic stroke. Blood Coagul Fibrinolysis 2014;25:61-66.

65. Carter AM, Catto AJ, Bamford JM, Grant PJ. Platelet GP IIla PIA and GP $\mathrm{Ib}$ variable number tandem repeat polymorphisms and markers of platelet activation in acute stroke. Arterioscler Thromb Vasc Biol 1998;18:1124-1131.

66. Duan H, Cai Y, Sun X. Platelet glycoprotein IIb/IIIa polymorphism HPA-3 b/b is associated with increased risk of ischemic stroke in patients under 60 years of age. Med Sci Monit 2012;18:19-24.

67. Saidi S, Mahjoub T, Slamia LB, Ammou SB, Al-Subaie AM,Almawi WY. Polymorphisms of the human platelet alloantigens HPA-1, HPA-2, HPA-3, and HPA-4 in ischemic stroke. Am J Hematol 2008;83:570-573.

68. Ridker PM, Hennekens CH, Schmitz C, Stampf MJ, Lindpaintner K. PIA1/A2 polymorphism of platelet glycoprotein IIIa and risks of myocardial infarction, stroke and venous thrombosis. Lancet 1997;349:385-388.

69. Slowik A, Dziedzic T, Turaj W, Pera J, Glodzik-Sobanska L, Szermer P, Malecki MT, Figlewicz DA, Szczudlik A. A2 Alelle of GpIIIa gene is a risk factor for stroke caused by large vessel disease in males. Stroke 2004;35:1589-1593.

70. Xin XY, Song YY, Ma JF, Fan CN, Ding JQ, Yang GY, Chen SD. Gene polymorphisms and risk of adult early-onset ischemic stroke: A meta analysis. Thromb Res 2009;124:619-624.

71. Somay G, Misırlı H, Güler M, Çalışkan T, Sayhan N, Erenoğlu YN Serebrovasküler hastalıklarda apolipoprotein $\mathrm{E}$ ve anjiotensin converting enzim gen polimorfizmi. Türk Beyin Damar Hastalıkları Dergisi 2002;8:113-117.

72. Markoula S, Giannopoulos S, Kostoulas C, Tatsioni A, Bouba I, Maranis S, Georgiou I, Kyritsis AP. Gender association of the angiotensin-converting enzyme gene with ischaemic stroke. J Renin Angiotensin Aldosterone Syst 2011;12:510-515.

73. Zhang Z, Xu G, Liu D, Fan X, Zhu W, Liu X. Angiotensin converting enzyme insertion/deletion polymorphism contributes to ischemic stroke risk: A metaanalysis of 50 case-control studies. Plos One 2012;7:1-9.

74. Kalita J, Somarajan BI, Kumar B, Mittal B, Misra UK. A study of ACE and ADD1 polymorphism in ischemic and hemorrhagic stroke. Clin Chim Acta 2011;412:642-646.

75. Gu L, Su L, Chen Q, Liang B, Qin Y, Xie J, Wu G, Yan Y, Long J, Wu H, Tan J, Dou W, Chen W, Wu P, Wang J. Association between the apolipoprotein E gene polymorphism and ischemic stroke in Chinese populations: New data and meta-analysis. Exp Ther Medi 2013;5:853-859.

76. McCarron Mo, Delong D, Alberts MJ. APOE genotype as a risk factor for ischemic cerebrovascular disease: a meta-analysis. Neurology 1999;12:13081311.

77. Boumendjel S, Khodja D, Hamri A, Benlatreche C, Abadi N. Apolipoprotein E polymorphism and cerebral stroke. Ann Biol Clin(Paris) 2013;71:21-26.

78. Kuusisto J, Mykk nen L, Kervinen K, Kes niemi YA, Laakso M. Apolipoprotein E4 phenotype is not an important risk factor for coronary heart disease or stroke in elderly subjects. Arterioscler Thromb Vasc Biol 1995;15:1280-1286.

79. Basun H, Corder EH, Guo Z, Lannfelt L, Corder LS, Manton KG, Winblad B, Viitanen M. Apolipoprotein E polymorphism and stroke in a population sample aged 75 years or more. Stroke 1996;27:1310-1315. 